\title{
peranan Bupati R.A.A. WIRATANuNIngrat DALAM PEMBangunaN KABUpateN TASIKMALAYA 1908-1937
}

\section{THE ROLE OF REGENT R.A.A WIRATANUNINGRAT IN DEVELOPMENT OF TASIKMALAYA REGENCY 1908-1937}

\begin{abstract}
Aam Amaliah Rahmat
Jurusan Ilmu Sejarah UNPAD

Jalan Raya Bandung Sumedang Km. 21 J atinangor

e-mail: amlira49@yahoo.com

Abstrak

Tulisan ini membahas tentang peranan Bupati R.A.A. Wiratanuningrat dalam membangun Kabupaten Tasikmalaya. Perkembangan tersebut meliputi bidang pendidikan, infrastruktur, agama, pertanian, dan ekonomi. Ada tiga hal yang dipersoalkan yaitu (1) bagaimana kondisi sosial, ekonomi dan pemerintahan sebelum R.A.A. Wiratanuningrat memerintah? (2) siapakah R.A.A. Wiratanuningrat? (3) bagaimana kondisi ekonomi, sosial, dan pemerintahan ketika R.A.A. Wiratanuningrat memerintah? Adapun metode yang digunakan untuk menjawab pertanyaan tersebut yaitu menggunakan metode sejarah yang terdiri dari heuristik, kritik, interpretasi dan historiografi. Kabupaten Tasikmalaya memang pada mulanya bernama Kabupaten Sukapura. Perpindahan ibukota dari Manonjaya ke Tasikmalaya boleh dikatakan sebagai tonggak awal untuk melakukan pembangunan di Tasikmalaya walaupun memang perpindahan ini tidak terjadi pada masa Wiratanuningrat memerintah. Meskipun Bupati R.A.A. Wiratanuningrat bukan keturunan langsung dari dinasti "wiradadaha" tetapi R.A.A. Wiratanuningrat dapat memperlihatkan kemajuan di Kabupaten Tasikmalaya baik dari segi fisik maupun nonfisik sehingga sampai sekarang dikenal sebagai bapak pembangunan dan bapak irigasi.
\end{abstract}

Kata kunci: R.A.A. Wiratanuningrat, Tasikmalaya, Bupati, Kabupaten.

\begin{abstract}
This paper discusses the role of Regent of R.A.A. Wiratanuningrat in building Tasikmalaya Regency. These developments include education, infrastructure, religion, agriculture, and economics. There are three points in question, namely (1) how social, economic and governance conditions before R.A.A. Wiratanuningrat ruled? (2) who is R.A.A. Wiratanuningrat? (3) how the economic, social, and governance conditions when R.A.A. Wiratanuningrat ruled? The method used to answer the question are using historical method consisting of heuristics, criticism, interpretation and historiography. Tasikmalaya Regency was originally named Sukapura Regency. The transfer of capital from Manonjaya to Tasikmalaya may be regarded as an early milestone for development in Tasikmalaya although indeed this movement did not occur during the reign of Wiratanuningrat. Although the R.A.A. Regent Wiratanuningrat is not a direct descendant of the dynasty "wiradadaha" but R.A.A. Wiratanuningrat can show a progress in Tasikmalaya Regency both physically and non-physically, so well known as the father of development and the father of irrigation.
\end{abstract}

Keywords: R.A.A. Wiratanuningrat, Tasikmalaya, Regent, Regency. 


\section{A. PENDAhuluan}

Kedudukan bupati pada zaman pemerintahan Hindia Belanda mengalami perubahan, yang mulai diberlakukan sejak Daendels menjadi Gubernur Jenderal (1808-1811). Perubahan tersebut yakni, sebagai pegawai Hindia Belanda yang diangkat oleh Gubernur Jenderal, yang ditandai dengan diberikannya gaji berupa uang (Yulifar, 2014: 19, Hardjasaputra, 2002: 40). Hal ini dilatarbelakangi oleh keinginan pihak kolonial untuk menegakkan kekuasaannya di tanah jajahan melalui pemerintahan secara langsung (direct rule). Tetapi, karena kuatnya tatanan pemerintahan tradisional, dengan bupati sebagai pemimpin kharismatis yang di mata rakyatnya, maka upaya Hindia Belanda tersebut sebenarnya tidak pernah berhasil secara utuh bahkan pada akhirnya gagal. Karena itu, peran dan posisi bupati pada saat ini mengalami dualisme, yakni pemimpin yang legalrasional (pegawai kolonial) dan tradisional-kharismatis.

Kendati keinginan Daendels (Pemerintah Kolonial) menginginkan pemerintahan seiring dengan berbagai cara untuk mengurangi kekuasaan bupati. Maka berbagai cara dilakukan di antaranya melalui intervensi terhadap pergantian bupati, bahkan berupaya dalam menghapuskan jabatan yang diwariskan, kemudian melakukan reorganisasi wilayah, menghadirkan jabatan patih, kontroleur, dan lain-lain. Namun demikian, kekuasaan bupati pada kabupaten yang dipimpinnya tetap besar, karena rakyat tunduk dan patuh pada bupati sebagai pemimpin tradisional yang berakar pada struktur sosial yang tersusun berdasar kelahiran (keturunan), kekayaan, dan status sosial (Kartodirdjo, 1982: 226 dan Mangunhardjana $\mathrm{Sj}, \quad$ 1976: 18 dalam Yulifar 2014: 23).

Peran dan posisi bupati yang dualisme tersebut, antara lain terjadi di wilayah Priangan, baik di Priangan Barat maupun Timur. Salah satu wilayah Priangan Timur yang menarik perhatian peneliti adalah daerah yang kini dikenal dengan sebutan Tasikmalaya, yang semula bernama Sukapura tahun 1913. Artinya perubahan tersebut terjadi pada masa pemerintahan Bupati R.A.A. Wiratanuningrat (1908-1937). Hal ini menjadi daya tarik bagi penulis untuk mengkaji kepemimpinan bupati R.A.A. Wiratanuningrat melalui penelitian dengan judul Peranan Bupati R.A.A. Wiratanuningrat dalam Pembangunan Kabupaten Tasikmalaya 1908-1937. Adapun permasalahan pokok dari penelitian ini adalah bagaimanakah rekam jejak R.A.A. Wiratanuningrat sebagai bupati Kabupaten Sukapura-Tasikmalaya tahun 1908-1937?

Buku yang membahas tentang Wiratanuningrat tidak ada, akan tetapi ada laporan penelitian yang membahasnya. Di sini penulis menggunakan buku-buku yang bahasannya tentang bupati meskipun tidak secara langsung membahas Wiratanuningrat.

Pertama, buku berjudul Bupati di Priangan karya A. Sobana Hardjasaputra. Buku ini menjelaskan mengenai pembukaan Rawalakbok tahun 1925 oleh Wiratanuningrat. Dalam buku ini didapat informasi mengenai perjuangan Bupati Wiratanuningrat dalam pembukaan Lakbok yang tadinya merupakan daerah yang terendam banjir, Wiratanuningrat akan menjadikan Lakbok sebagai areal pertanian demi meningkatkan ekonomi masyarakat.

$\begin{array}{ccr}\text { Kedua, } & \text { Peranan } & \text { R.A.A. } \\ \text { Wiratanuningrat } & \text { sebagai } & \text { Bupati } \\ \text { Pembangunan Awal Abad } & \text { ke-20 di }\end{array}$ Tasikmalaya yang merupakan laporan penelitian. Laporan penelitian ini diketuai oleh Itje Marlina. Isinya membahas keadaan daerah Tasikmalaya dilihat dari aspek geografis, demografi, sosialekonomi, serta Kabupaten SukapuraTasikmalaya di bawah Pemerintahan Wiratanuningrat.

Ketiga, buku karya Nina Herlina Lubis yang berjudul Kehidupan Kaum Ménak Priangan 1800-1942. Buku ini 
membahas tentang peranan para bupati yang pada mulanya diangkat oleh Raja Mataram dan setelah dikuasai oleh VOC diangkat oleh Gubernur Jenderal.

Keempat, buku berjudul Sejarah Kota Tasikmalaya 1820-1942 yang ditulis oleh Miftahul Falah. Di dalam buku ini dibahas mengenai sejarah Kota Tasikmalaya yang komprehensif dilihat dari aspek perubahan sosial. Buku ini memberikan informasi mengenai perbedaan Kabupaten Tasikmalaya, Kota Tasikmalaya sehingga penulis tidak kebingungan antara kedua istilah tersebut.

Kelima, buku Sejarah Kota-Kota Lama di Jawa Barat yang ditulis oleh Nina H. Lubis dkk. Di dalamnya terdapat bab yang ditulis oleh Ietje Marlina mengenai Sukapura (Tasikmalaya). Dalam tulisannya, Ietje menjelaskan mengenai kedudukan Ibu Kota Sukapura sebelum berkedudukan di Tasikmalaya dan menjelaskan mengenai awal mula asal kata Tasikmalaya sampai perkembangan Sukapura yang pada akhirnya berganti menjadi Tasikmalaya.

\section{B. METODE PENELITIAN}

Metode yang digunakan dalam penelitian ini adalah metode sejarah yang terdiri dari empat tahap, yaitu heuristik, kritik, interpretasi, dan historiografi. Tahap pertama yang dilakukan dalam metode sejarah adalah heuristik yang merupakan sebuah tahapan atau kegiatan menemukan dan menghimpun sumber, informasi, jejak masa lampau (Herlina, 2014: 7-15).

Tahap kedua adalah kritik yaitu memilah dan memilih juga menyaring keotentikan sumber-sumber yang telah ditemukan. Pada tahap ini peneliti melakukan pengkajian terhadap sumbersumber yang didapat untuk kebenaran sumber. Ada dua hal yang perlu dilakukan pertama meneliti otentisitas sumber atau keaslian sumber disebut kritik eksternal. Kedua meneliti kredibilitas sumber yang disebut kritik internal (Kuntowijoyo, 2013: 77-78).
Tahap ketiga yaitu interpretasi, memaknai atau memberikan penafsiran terhadap fakta-fakta yang diperoleh dengan cara menghubungkan satu sama lainnya untuk memperoleh fakta sejarah mengenai hal tertentu. Lalu melakukan koroborasi suatu data dari suatu sumber sejarah dengan sumber lain (dua atau lebih). Menurut Herlina interpretasi yaitu tahapan atau kegiatan menafsirkan fakta-fakta serta menetapkan makna dan saling hubungan dari fakta-fakta yang diperoleh (Herlina, 2014:15).

Tahap keempat adalah historiografi. Dalam bahasa Inggris Historiografi didefinisikan sebagai pengkajian tentang penulisan sejarah (Barnes, 1963 dalam Herlina, 2009: 9). Sedangkan menurut Gottschalk historiogarfi diartikan sebagai rekonstruksi imajinatif dari masa lampau berdasarkan data yang diperoleh dengan menempuh proses.

\section{HASIL DAN BAHASAN \\ 1. Kabupaten Sukapura 1901-1908}

Paruh pertama abad ke-17 sampai awal abad ke-20 (1908) dikenal dengan kepemimpinan para bupati Sukapura yang oleh sementara orang dianggap sebagai keturunan atau 'dinasti' Wiradadaha, yang memerintah sekitar tahun 1641 dimulai dari Wiradadaha I (1641-1674) sampai dengan Wiradadaha XII yang mendapat sebutan Dalem Bintang (1875-1901). Periode berikutnya, Kabupaten Sukapura dipegang oleh Dalem Bogor bernama R.T. Wiraadiningrat, yang memerintah dari tahun 1901 sampai dengan 1908. Di bawah kepemimpinan bupati inilah pusat kota Kabupaten Sukapura dari Manonjaya dipindahkan ke Tasikmalaya. Dia bupati pertama yang mendapat gelar aria, sehingga terkenal dengan sebutan Dalem Aria. Setelah wilayah afdeeling Mangunreja menjadi bawahan Sukapura, dan afdeeling Cikajang menjadi bawahan Kabupaten Limbangan, sedangkan Distrik Malangbong dibagi dua, yakni sebagian bawahan Limbangan dan sebagian bawahan Sumedang, sejak itulah, Sukapura berubah nama menjadi Tasikmalaya. 
Pada awalnya daerah yang disebut Sukapura itu bernama Tawang atau Galunggung. Sering juga disebut TawangGalunggung. Tawang berarti 'sawah' atau 'tempat yang luas terbuka'. Penyebutan Tasikmalaya muncul untuk pertama kali setelah Gunung Galunggung meletus sehingga wilayah Sukapura berubah menjadi Tasik 'danau, laut' dan malaya dari (ma)layah bermakna 'ngalayah (bertebaran)' atau 'deretan pegunungan di pantai Malabar (India)'. Tasikmalaya mengandung arti 'keusik ngalayah', maksudnya banyak pasir di mana-mana.

Setelah R.A. Wiraadegdaha diturunkan dari jabatannya, sebagai penggantinya adalah adiknya R. Demang Danukusumah, patih Manonjaya. Setelah menjadi bupati namanya menjadi R.T. Wirahadiningrat, bupati Sukapura ke-12, memerintah dari tahun 1875-1901. R.T. Wirahadiningrat adalah bupati terakhir yang tinggal di Manonjaya. Pada tahun 1893 ia diberi gelar adipati, tahun 1898 mendapat Payung Kuning, dan pada tahun 1900 ia mendapat bintang Oranye Nassau. Itulah sebabnya Bupati R.T. Wirahadiningrat mendapat sebutan Dalem Bintang. R.T. Wirahadiningrat terkenal sabar, adil, dipercaya pemerintah kolonial dan mencintai keluarganya.

Sebagai ganti atas hak-hak bupati, para bupati kembali menerima surat pengangkatan dari Gubernur Jenderal sebagai pegawai pemerintah (Besluit Gubernur Jenderal 5 Mei dan 20 Juni 1871). Berdasarkan besluit itu para Bupati Priangan menerima gaji (pertahun) cukup tinggi dengan tunjangan cukup besar pula. Contohnya Bupati Sukapura mendapat gaji sebesar $f$ 20.000. Di samping gaji tetap yang dibayar tiap bulan, bupati juga mendapat bagi hasil dari kopi sebesar $f 1$ per pikul dengan ketentuan tidak lebih dari $f \quad 6.000$ untuk Bupati Sukapura (Martanegara, 1923: 21 dalam Marlina, 1988: 34).

Pendapatan para bupati itu ditambah lagi dengan hasil sawah-lungguh (kalungguhan) atau sawah carik yang luasnya ratusan bahkan ribuan bau. Pendapatan Bupati Priangan cukup mencolok bila dibandingkan dengan bupati-bupati di daerah lain. Misalnya Bupati Semarang dan Surabaya, masingmasing hanya menerima gaji $f 14.000$ dan tunjangan $f 2.400$ per tahun.

Data tentang penghasilan Bupati Sukapura tersebut menunjukkan bahwa Bupati Priangan walaupun kedudukannya telah dipojokkan menjadi pegawai yang tidak memiliki kekuatan dalam sistem administrasi pemerintahan, tetapi tetap memiliki fungsi dan peranan penting sebagai pengatur produksi agraria dalam eksploitasi kolonial Belanda. Faktor inilah yang menyebabkan posisi Bupati Priangan berbeda dengan bupati di daerah lain (Hardjasaputra, 1985: 45).

Walaupun para bupati Priangan umumnya memiliki tanggungan keluarga dalam jumlah besar, tetapi karena penghasilan tinggi dan kaya akan harta benda, mereka dapat hidup berkecukupan (Sutherland, 1979: 22).

Pada masa Gubernur Jenderal W. Rooseboom dikeluarkan peraturan/ keputusan No. 218 tertanggal 10 Agustus 1900, yaitu tentang penghapusan batas keresidenan, kabupaten, afdeeling, distrik dan onder distrik serta peraturan pembagian batas keresidenan dan kabupaten yang baru.

Pada tahun 1901 Kabupaten Sukapura mendapat perubahan besar yaitu afdeeling Mangunreja dan Tasikmalaya dihilangkan serta bawahannya diperintah langsung oleh bupati, tapi tidak semuanya. Dari afdeeling Mangunreja yang masuk ke Sukapura ialah distrik-distrik: Mangunreja, Deudeul, Taraju, Sukaraja, Karang, dan Parung. Sisanya yaitu Cikajang, Batuwangi, Kandangwesi, dan Nagara dimasukkan ke dalam Kabupaten Limbangan. Dari afdeeling Tasikmalaya yaitu Ciawi, Indihiang dan Singaparna, sedangkan distrik Malangbong dibagikan kepada kedua kabupaten yaitu sebagian ke Kabupaten Limbangan dan sebagian lagi ke Sumedang. Mulai saat itu distrik-distrik 
bawahan Sukapura banyak yang dihilangkan atau disatukan dengan kabupaten lain. Pada tahun 1910 yang berada di bawah kekuasaan Kabupaten Sukapura hanya tinggal 14 distrik lagi.

Bupati yang memerintah dari tahun 1901-1908 yaitu R. Rangga Wiratanuwangsa. Setelah menjadi bupati namanya diganti menjadi R.T. Prawiraadiningrat, Bupati Sukapura ke-13. Pada era kepemimpinannya perpindahan ibu kota dari Manonjaya ke Tasikmalaya dilaksanakan.

Pada tanggal 22 November 1901 Pemerintah Hindia Belanda mengeluarkan Besluit No. 33 yang isinya menetapkan bahwa sejak tanggal 1 Desember 1901, Kota Tasikmalaya menggantikan Manonjaya sebagai Ibu kota Kabupaten Sukapura (Besluit 22 Nopember 1901 No.33 Staatsblad van Nederlansch Indie). Ada dua pendapat mengenai penyebab perpindahan Ibu Kota Kabupaten Sukapura dari Manonjaya ke Kota Tasikmalaya. Pertama, alasan ekonomi yaitu terkait dengan proses penanaman, penyimpangan, dan pengiriman nila (tarum). Penanaman nila dilaksanakan di daerah Gunung Galunggung dan gudang penyimpanannya terletak di daerah Pataruman, Kota Tasikmalaya. Oleh karena penanaman nila menjadi tanggung jawab bupati, proses pengawasan akan mengalami kesulitan karena jarak dari Manonjaya ke Galunggung cukup jauh. Kedua, alasan geografis karena pada kenyataannya Kota Tasikmalaya memiliki tanah datar yang jauh lebih luas daripada Manonjaya. Manonjaya terletak di sebuah dataran sempit yang berbukit-bukit sehingga sulit untuk dikembangkan. Berbeda dengan Kota Tasikmalaya yang memiliki dataran yang sangat luas sehingga dipandang lebih cocok untuk dijadikan sebagai ibu kota kabupaten (Marlina, 2007: 92-93; Falah, 2010: 60).

Dengan demikian maka alasan perpindahan ibu kota bukan hanya karena semata-mata masalah kondisi morfologi tanah Kabupaten Tasikmalaya tetapi juga karena aspek kestrategisan daerah itu. Delapanbelas tahun kemudian, setelah Tasikmalaya dijadikan ibu kota Kabupaten Sukapura, Manonjaya menjadi sebuah distrik (Regeering almanak voor Nederlandsch-Indie, 1919).

\section{Kabupaten Tasikmalaya di Bawah Kepemimpinan R.A.A. Wiratanuningrat}

Kanjeng R.A.A. Wiratanuningrat lahir pada 19 Februari 1878. R.A. Wiratanuningrat merupakan putra Bupati Sukapura sebelumnya yaitu Tumenggung Aria Prawira Adiningrat. Ayahandanya tersebut adalah anak Raden Adipati Wiraadegdaha pensiunan Bupati Sukapura yang tinggal di Karangpucung. Buyut dari Kanjeng Dalem Tumenggung Danuningrat (Bupati ke-9). Dengan demikian, Wiratanuningrat adalah bupati yang memiliki darah (warisan) dari bupati sebelumnya yang berasal dari Dalem Bogor dengan nama sebelum menjadi bupati adalah R. Rangga Wiratanuwangsa (Marlina 2000: 106). Dengan demikian, Wiratanuningrat adalah Bupati di Sukapura, sebagaimana ayahnya, yang bukan dari Dinasti Wiradadaha.

R.A. Wiratanuningrat menikah dengan Raden Ayu Rajapamerat, puteri Raden Jayadiningrat seorang jaksa di Landraad Cianjur. Isterinya tersebut adalah cucu perempuan dari Raden Adipati Aria Martanegara ${ }^{1}$. Karena perkawinannya ini Bupati Wiratanuningrat memiliki hubungan dengan semua bupati di Priangan, Rangkasbitung, dan patih Sukabumi.

Pendidikan formalnya diperoleh dari sekolah Belanda di Sukabumi selama 2 tahun, kemudian dipindahkan ke sekolah Belanda di Bogor. Setelah 2 tahun lamanya belajar di sekolah tersebut, ketika umur 12 tahun ia masuk ke sekolah ménak (Hoofden School) di Bandung sampai

\footnotetext{
${ }^{1}$ R. Ayu Radjapamerat lahir 3 Januari 1893, ibunya bernama R. Ayu Tedjapamerat (Wirahadi Soeria, tt: 15).
} 
tahun 1896. Sekolah ménak adalah sekolah untuk mendidik calon pegawai pangreh praja (sekarang: Pegawai Negeri). Calon murid yang akan masuk ke sekolah ini harus memenuhi syarat berikut: telah duduk di kelas 7 HIS atau kelas 6 ELS dan harus bisa berbahasa Melayu di samping bahasa daerahnya sendiri. Selain itu umur tidak boleh lebih dari 15 tahun dan diutamakan anak kaum ménak (Lubis, 1998: 214).

Menurut surat Keputusan Residen tanggal 5 April 1897, No. 2932/8, R.T. Wiratanuningrat ditugaskan sebagai Joeroe Serat Controluer Bandung Utara. Dia bertugas di wilayah tersebut kurang lebih 3 tahun lamanya. Berdasarkan surat Keputusan Residen tertanggal 5 Oktober 1901, No. 123-97/8, R.T. Wiratanuningrat menerima pengangkatan menjadi Asisten Wedana di Andir, wilayah Ujung Berung Barat.

Setelah kurang lebih 7 tahun memegang jabatan tersebut di atas, berdasarkan surat keputusan pemerintah tertanggal 12 Februari 1908, No. 26, ia menerima pengangkatan sebagai wedana di wilayah Ciheulang daerah Sukabumi. Setelah 7 bulan menjabat di Ciheulang, dengan keputusan pemerintah yang telah dijanjikan dalam pembangunan, mengolah serta mengatur urusan pemerintahan, maka berdasarkan surat keputusan pemerintah tertanggal 23 Agustus 1908, No. 2 R.T. Wiratanuningrat diangkat menjadi Bupati di Sukapura. Gelar Adipati diperolehnya pada tanggal 1 Agustus 1920 No.1 (Conduitestaat, 1925). Oleh karena itu, jabatan bupati yang diperolehnya melalui sebuah proses yang cukup panjang (11 tahun) dan berjenjang, yang dimulai dari jabatan juru tulis kontroleur, asisten wedana (sekarang: camat), dan wedana. Menilik portofolionya tersebut, bupati tersebut cukup punya pengalaman dalam memegang sebuah wilayah yang cukup bergengsi. Demikian juga bupati-bupati di daerah yang lain pada umumnya memiliki pengalaman jabatan yang rata-rata dimulai dari strata bawah.
Terkait lamanya masa karier menuju Bupati, Lubis (1998: 104) menjelaskan bahwa 'masa tunggu' yang paling singkat diperoleh Bupati Galuh R.A.A. Kusumasubrata dari jabatan sebagai Mantri Kabupaten (1883) menuju kepada jabatan bupati hanya dalam tempo 3 tahun tanpa mengalami dulu menjadi wedana atau patih. Sedangkan yang paling lama adalah R.A.A. Martanegara, selama 32 tahun untuk menjadi Bupati Bandung (1893). Menurut Lubis (1998: 106), hal ini terjadi disebabkan faktor keturunan langsung dan tidak merupakan keturunan langsung dari bupati yang digantikannya (sehingga lama dalam menempuh jenjang karier menuju bupati).

Bupati R.A.A Wiratanuningrat memiliki empat istri, satu garwa padmi dan 3 selir (Marlina, 1988). Istrinya yang pertama (garwa padmi) bernama Raden Ayu Rajapamerat. R.A.A. Wiratanuningrat dari pernikahannya tersebut memiliki 19 orang putera dan puteri. Bupati ini mendapat sebutan Aom Soleh. Sebutan ini disebabkan dia taat pada agama, bersikap baik dan berpembawaan tenang, walaupun cenderung pendiam sehingga berkesan tertutup (Conduitestaat 1925 Agustus No $745 / 26$ ). Tentang pribadi yang baik dan pendiam tersebut juga digambarkan dalam Conduitestaat Tahun 1913 No. 1715/14. Sikap pendiam tersebut menurut conduitestaat berupaya ditutupi dengan bersikap riang (ramah?), dan bertindak bijaksana, serta berhati-hati di dalam setiap mengambil keputusan. Pribadi bupati yang seperti itu membuat dia dicintai rakyatnya. Kemudian dijelaskan bahwa jika berhadapan dengan orang-orang Eropa (Belanda) dia bersikap sangat sopan, tetapi tegas kepada pihak pribumi yang berada di bawah kepemimpinannya. Oleh karena itu, bupati R.A.A. Wiratanuningrat bukan hanya dicintai oleh aparat dan rakyatnya, juga mendapat kepercayaan dari Pemerintah Kolonial. Namun demikian, riwayat pernikahannya yang memiliki lebih dari satu istri, dikritisi pihak kolonial sebagai sebuah catatan tentang konditenya 
dalam berhubungan dengan kaum perempuan. Tidak mengherankan, sebab mereka mengenal perkawinan dalam konsep monogami.

Hampir semua Bupati di abad ke-19 melakukan poligami, mempunyai istri utama, raden ayu atau padmi, yang derajatnya setara dengan sang Bupati dan biasanya putri dari bupati lain. Kemudian terdapat istri-istri kedua yang disebut selir atau ampeyan. Anak-anak dari istri-istri kedua mempunyai status yang lebih rendah daripada anak-anak dari istri padmi (Sutherland, 1983: 60).

Sebagai bupati, R.A.A. Wiratanuningrat memiliki dua gelar yaitu gelar kebangsawanan ${ }^{2}$ dan gelar jabatan ${ }^{3}$ yang menurut Kartodirdjo (1987: 27) dipakai di depan nama, bahkan nama itu sendiri sering mengidentifikasikan kebangsawanan dan jabatannya pada pemerintahan.

Karena jasa-jasanya, Bupati Wiratanuningrat mendapat penghargaan dari pemerintah, berdasarkan surat keputusan pada tanggal 21 Agustus 1920 No. 1 mendapat gelar adipati. Pada 24 Agustus 1922 No. 39 mendapat bintang Offisier der Orde van Oranje Nassau. Berdasarkan besluit tertanggal 21 Agustus 1926 No. 13 ia mendapat Gale Songsong. Kemudian, mendapatkan Bintang Mas Besar, sebagai penghargaan atas jasajasanya kepada 'negeri' yang diberikan bersamaan dengan perayaan 25 tahun dia

${ }^{2}$ Gelar kebangsawanan merupakan gelar yang diturunkan secara turun-temurun seperti raden, pangeran. Selain itu, ada gelar yang diperoleh karena perkawinan dengan wanita dari kalangan bangsawan. Dalam hal ini, gelar yang diperoleh bisa diwariskan secara turun-temurun dan akhirnya menjadi gelar kebangsawanan (Lubis, 1998: 153).

${ }^{3}$ Gelar jabatan merupakan gelar yang diperoleh karena jasa atau pengabdian kepada pemerintah yang biasanya menyertai suatu promosi jabatan seperti adipati, tumenggung, rangga, ngabehi, dan demang (Lubis, 1998: 153). memerintah (Pandji Poestaka No. 69, 29 Agustus 1933).

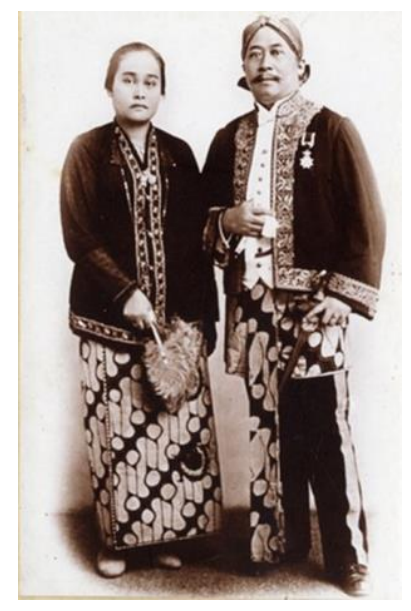

Gambar 1. R.A.A. Wiratanuningrat dengan Istrinya Raden Ayu Rajapamerat Sumber: Koleksi KITLV. Diakses dari http://media-kitlv.nl/all-

media/indeling/detail/form/advanced/start/226

$? q \_$searchfield=tasikmalaja, Tanggal 16 Juni 2017, Pukul 19.32 WIB.

\section{Kiprah R.A.A. Wiratanuningrat pada Sepuluh Tahun Terakhir Masa Pemerintahannya}

Di bawah kepemimpinan R.A.A. Wiratanuningrat, Kabupaten Sukapura mengalami kemajuan yang sangat pesat. Pembangunan di segala bidang telah berhasil dengan baik, sehingga mendapat tanggapan yang positif dari pemerintah kolonial. Oleh karena itu, bupati ini mendapatkan banyak penghargaan dari pemerintah kolonial, dan dicintai masyarakat Sukapura yang merasakan langsung kemajuan pada berbagai bidang selama bupati tersebut memerintah.

Melalui kiprahnya tersebut, diketahui bahwa dalam pengembangan Tasikmalaya, Bupati Wiratanuningrat lebih berperan dalam kedudukannya sebagai kepala daerah, karena pengembangan pusat kabupaten adalah tanggung jawab bupati. Bupati Wiratanuningrat dalam menyampaikan instruksi pemerintah kolonial kepada rakyat mampu memanfaatkan kebijakan pemerintah tersebut untuk kepentingan pemerintah 
kolonial, tetapi ia juga memperhatikan kepentingan dan kesejahteraan rakyatnya. Usaha-usaha Bupati Wiratanuningrat dalam memajukan kesejahteraan rakyat yaitu di bidang: agama, pendidikan, pembangunan fisik, transportasi, ekonomi dan pertanian.

Pada masa pemerintahan Bupati Wiratanuningrat di Tasikmalaya, bidang pertanian sangat mendapat perhatian. Bupati ini melakukan pembangunan pada berbagai bidang dalam rangka memajukan kehidupan ekonomi dan sosial-budaya. Karena mata pencaharian rakyatnya adalah bertani, maka bidang ini sangat diperhatikan dengan serius. Misalnya dengan jalan memperluas lahan pertanian pada tanah atau lahan yang tadinya tidak terpakai (ekstensifikasi). Di dalam upaya pembukaan lahan baru tersebut dia melibatkan rakyatnya, dan berhasil dengan gemilang. Hal ini menjadikan bupati tersebut dikenal berhasil dalam memajukan pertanian sehingga Kabupaten Tasikmalaya bertambah maju. Salah satu contohnya ialah pembukaan hutan Gagayunan menjadi lahan pertanian, dan ngabukbak (membuka lahan) Rawa Lakbok pada tahun 1923.

Salah satu jasa yang paling terkenal dari R.A.A. Wiratanuningrat adalah membuka rawa-rawa menjadi areal pesawahan, yang dikenal dengan istilah ngabukbak Lakbok (Membuka lahan di daerah Lakbok, saat ini menjadi bagian dari wilayah administratif Kota Banjar). Rawa Lakbok terdiri dari dua bagian yaitu Lakbok Utara dan Lakbok Selatan, luasnya Lakbok Utara kurang lebih 5931 ha dan Lakbok Selatan 600 ha. Sampai tahun 2583 (1923) tanah-tanah datar tersebut di atas masih rawa yang dipenuhi oleh tanaman-tanaman serta belukar dengan udara yang tidak sehat. Tujuan pembukaan lahan ini adalah menjadikan daerah yang awalnya tidak produktif menjadi produktif sehingga menjadi penghasil beras yang potensial.

Rawa yang asalnya merupakan rimba yang lebat dan belum pernah diinjak oleh manusia, kini setelah dijadikan areal persawahan oleh Bupati Wiratanuningrat, yang kemudian melahirkan kampungkampung kecil di sekitarnya. Karena itu tidak mengherankan jika masyarakat di sekitarnya menganggap tempat 'keramat', bahkan dikenal dengan sebutan 'onom Rawa Lakbok" (mahluk halus yang menguasai Rawa Lakbok). Bahkan, dipercaya sebagian masyarakat bagaimana "onom" tersebut "menjadi tuah" bagi para bupati yang berkuasa di Galuh (Ciamis).

Beberapa "besotan" dan saluran air digali untuk membuang air rawa ke Cilisung, Ciseel, Citanduy terus ke lautan Hindia. Pohon-pohon ditebang dan belukar-belukar dibabat, kegiatan ini dipimpin oleh bupati sendiri dibantu oleh rakyat yang terus menerus bekerja dengan giat. Tak berapa lama rawa yang tadinya hanya menjadi sarang malaria dan ular, telah berubah menjadi sumber penghasilan bagi beribu-ribu petani. Desa-desa sekitar Rawa Lakbok yang terbilang besar yaitu di antaranya Pataruman, Ciawitali dan Sindangangin.

Sepuluh tahun kemudian, wilayah rawa yang tadinya merupakan rimba yang lebat dan belum pernah diinjak oleh manusia, kini menjelma menjadi lahan pertanian dan tumbuh desa-desa di sekitar Rawa Lakbok. Desa-desa tersebut terbilang besar, di antaranya Pataruman, Ciawitali, dan Sindangangi. Seiring dengan itu, peningkatan dalam bidang pertanian sangat signifikan. Karena itu tidak mengherankan jika jumlah penduduk di Lakbok tahun 1933 menjadi berjumlah \pm 20.944 orang dan terus bertambah pada tahun-tahun berikutnya, sehingga lima tahun kemudian berada pada angka Pada tahun 2598 (1938) bertambah menjadi 30.078. Mereka mendapatkan sumber penghidupannya dari pertanian dan perikanan. Dengan demikian, sebagai bupati, R.A.A. Wiratanuningrat telah berhasil membangun masyarakatnya ke arah yang lebih sejahtera sesuai dengan potensi sumber daya alam dan sumber daya manusianya. Artinya, dia memiliki 
jiwa kepemimpinan dan kemampuan menejerial sebagai kepala daerah, sekaligus pemimpin tradisional.

Hal ini diperlihatkan oleh kemahirannya di dalam mengembangkan sebuah lahan yang memiliki luas dengan lebarnya tanah yang sudah dapat dikerjakan sebagai sawah kira-kira 6300 ha sedangkan yang sudah dijadikan tegalan dan huma 4600 ha. Menurut tinggi rendah letaknya, sawah-sawah dibagi atas beberapa golongan yaitu sawah gogo ranca, sawah biasa, sawah ledok, dan sawah embel. Sebagian dari Rawa Lakbok dapat ditanami padi cere dan gadu dua kali setahunnya, tetapi sawah embel hanya dapat dikerjakan pada saat musim hujan saja. Hal ini disebabkan dalam pengerjaannya yang terburu-buru karena khawatir keburu datang banjir, di samping bibitnya memang bukan berasal dari jenis bibit unggul.

Penghasilan dari embel gitak ratarata hanya 15 kuintal per hektarnya. Tetapi sebenarnya rakyat bukan hanya memperoleh hasil panen padi saja, sebab mereka menanami bagian tertentu dari sawah yang ketika musim kering, ada bagian yang masih tergenang air. Sawahsawah yang ditanami ketika musim hujan, tanpa ada teknologi irigasi disebut sawah tadah hujan.

Permasalahan yang dihadapi Rawa Lakbok adalah manakala musim hujan volume air hujan tinggi yang membuat sungai Ciseel dan Citanduy meluap. Akibatnya terjadi banjir, sementara air untuk dikonsumsi susah diperoleh. Akibat banjir tersebut bukan hanya merusak tanaman, terutama padi, tetapi juga merendam rumah-rumah penduduk. Lebih jauh lagi, dampak banjir akan berakibat kepada menurunnya kesehatan masyarakat. Kondisi sebaliknya pada musim kemarau, tanah ini menjadi kering dan iklimnya menjadi bersuhu tinggi sehingga udaranya terasa panas. Hal ini disebabkan oleh tingginya yang hanya $10 \mathrm{~m}$ dari permukaan laut. Oleh sebab itu, hampir setengahnya dari persawahan yang tidak dapat ditanami padi karena kekurangan air. Oleh karena itu, pertanian di daerah ini terkadang bisa surplus, atau sebaliknya. Ketika panen berhasil, ribuan orang datang dari manamana untuk mencari pekerjaan sebagai "pembawon" (pemotong padi). Mereka yang datang ternyata banyak yang berperan sebagai para tengkulak yang datang untuk membeli padi lalu dibawa ke tempat penggilingan-penggilingan beras milik orang Tionghoa. Seringkali padi yang dipotong belum begitu masak betul akibatnya harga padi menjadi rendah sekali. Kelompok yang diuntungkan dari rekayasa potensi Lakbok bukan lagi petani melainkan tengkulak-tengkulak dan para pemilik heleur atau yang punya penggilingan beras.

Pada musim kemarau sawah-sawah yang tidak terlalu kering ditanami dengan padi gadu dan palawija, terong, lombok, kacang, tembakau dan lain-lain. Tanah yang agak tinggi dan kering dengan singkong dan jagung. Singkong tersebut dapat dijual ke pabrik-pabrik aci di Bantardawa dan Cisaar. Artinya, pemahaman terhadap morfologi tanah digunakan untuk menentukan pengelolaan tanah tersebut. Sehingga, akan terjadi optimalisasi pemanfaat Sumber daya Alam (SDA).

Sayangnya, pada perkembangan berikutnya, ribuan bau tanaman singkong di lereng-lereng gunung sudah tidak dipelihara lagi, karena penuh dengan alang-alang dan belukar. Sebenarnya jika tanah-tanah ini tidak dibiarkan tetapi dicoba direkayasa dengan sistem-sengked, kemudian ditanami tanaman palawija seperti kacang kedelai atau jenis tumbuhan lain maka persediaan makanan akan banyak. Di sinilah perlunya seorang pemimpin yang kreatif.

Bukan hal yang mudah ketika mereka dihadapkan pada masalah banjir di satu sisi, dan kekurangan air di sisi lainyang timbul pada musim yang berbeda benar-benar merupakan kondisi yang ekstrem. Belum lagi permasalahan yang ditimbulkan oleh hama semacam hama 
merah dan hama dari binatang pengerat (tikus).

Pada bulan Agustus-September orang beramai-ramai menangkap ikan gabus, lele, betok dan belut di rawa-rawa terutama di Panglelean dan Rawa Sumur di wilayah Lakbok Selatan. Ikan-ikan tersebut ada yang dijual hidup-hidup ada yang dibikin "lauk garang" dan dikirim ke Bandung, Banjar, Tasikmalaya, dan ke seluruh Priangan. Oleh semacam Dinas Perikanan dianjurkan untuk menanam ikan "sepat siem". Oleh karena itu, setiap tahun menurut catatan-catatan tidak kurang dari $240.000 \mathrm{~kg}$ ikan yang ditangkap dapat dijual dengan harga $f 35.000-40.000$.

Genangan air pada musim kemarau membuat penduduk Lakbok senantiasa diserang oleh penyakit "muriang" (malaria sawah) yang setiap tahun memakan korban. Tempat yang paling baik untuk menternakkan nyamuk-nyamuk bukan rawa-rawa yang seringkali kebanjiran tetapi rawa-rawa kecil dan kolam-kolam di antara bukit-bukit yang ada di sekitar Lakbok. Air di rawa-rawa terlalu keruh bagi jentik-jentik Anopheles. Berikut ini beberapa hal yang memperlambat majunya Rawa Lakbok, yaitu:

a. Banjir di musim hujan;

b. Kekurangan air di musim kemarau;

c. Hama tikus dan hama merah;

d. Terputusnya perhubungan antara desa-desa, oleh karena terendamnya jalan-jalan;

e. Penyakit malaria.

Sawah-sawah di Lakbok dan di sekitar Banjar dan Rancakole semuanya sawah tadah hujan. Oleh karena itu sebagian besar pada musim kemarau tidak dapat dikerjakan karena kekurangan air. Buat mengairi Lakbok dirancang mengambil air dari Citanduy. Kira-kira 20 $\mathrm{km}$ dari arah hilir daerah Banjar dekat Desa Leuwikeris akan dibuat bendungan yang besar, yang akan mengalirkan airnya kurang lebih pada lahan 11.531 ha sawah. Sawah-sawah tadah hujan dekat Banjar dan Rancakole akan mendapat air dari Citanduy juga dengan saluran lain yang tidak memakai bendungan.

Jika pengairan sudah teratur $4 / 5$ dari sawah-sawah Lakbok di musim kemarau akan dapat ditanami dengan padi gadu. Sekarag hanya setengah yang dapat diambil hasilnya di musim kemarau. Diharapkan dengan adanya saluran-saluran pengairan, rawa-rawa yang masih dalam dapat dialiri dengan air Citanduy yang mengandung banyak lumpur hingga lama kelamaan akan tertutup dan dapat dijadikan sawah. Kesehatan rakyat akan lebih baik lagi karena sarang malaria menjadi berkurang. Penanaman padi dapat diatur secara bersama-sama, pemberantasan hama tikus dan hama merah akan lebih mudah.

Tidak diketahui sejak kapan masyarakat Tasik mulai memiliki keterampilan dalam menghasilkan barangbarang kerajinan yang penuh dengan kreatifitas. Yang jelas, pada masa pemerintahan R.A. Wiratanuningrat, rakyat Tasikmalaya dikenal sebagai penghasil industri kerajinan yang memiliki daya tarik yang tinggi. Kerajinan tangan yang dihasilkan adalah barang anyaman, kain batik, tikar, topi, tempat bunga, kursi, dan barang-barang lain dari bambu, kayu dan tempurung. Anyaman yang jadi bahan bakunya bisa dari bahan agro yang terdiri dari pandan yang banyak ditanam petani lokal, bambu, dan rotan.

Pada awal abad ke-20, industri batik di Tasikmalaya tersebar di beberapa sentra antara lain Burujul, Buniagara, Cipedes, Gudang Jero, Gudang Pasantren, Bojong Kaum, Panglayungan, dan Sayuran. Berdasarkan data dari sumber sekunder, kegatan membatik di Tasikmalaya dimulai sekitar akhir abad XVII dan awal abad XVIII (Falah, 2010: 162). Perkembangan seni membatik kemudian menjadi sebuah industri rumah tangga bahkan menjadi salah satu komoditas penting dalam perdagangan di Tasikmalaya. 


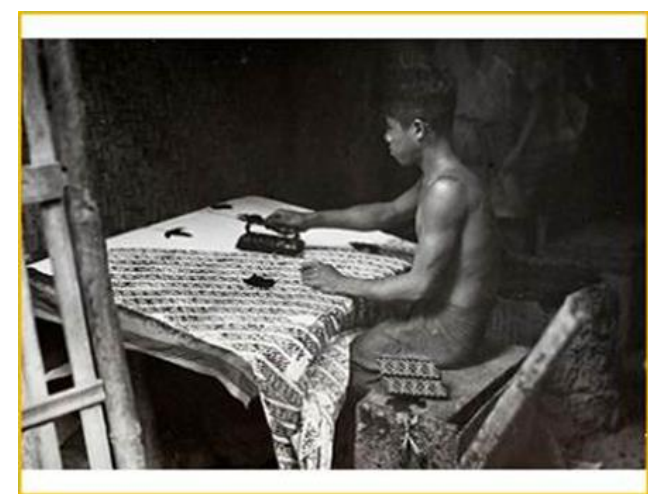

Gambar 2. Pengrajin Batik (1925)

Sumber: Koleksi Tropenmuseum.nl. Diakses dari

http://collectie.wereldculturen.nl/default.aspx?l ang=en, Tanggal 16 Juni 2017, Pukul 08.10 WIB.

Foto di atas memperlihatkan perajin batik di Kabupaten Tasikmalaya, yang sudah menggunakan teknik membatik berupa alat dalam bentuk cap. Karena itu, memungkinkan dikerjakan oleh kaum lakilaki. Karena, perajin batik tulis biasanya kaum perempuan. Penggunaan alat berupa cap tersebut akan mengakibatkan kapasitas produksi yang dihasilkan akan jauh lebih banyak dibanding dengan batik yang dibuat dengan cara ditulis. Dimungkinkan, pada tahun-tahun tersebut, kabupaten ini memiliki pasar yang luas, sehingga akan membuka lapangan kerja dan pendapatan masyarakatnya meningkat.

Tahun 1930 pengusaha batik di Tasikmalaya terkena imbas Krisis Ekonomi Dunia (Malaise) karena daya masyarakat menjadi lemah. Selain itu juga para pengusaha batik kesulitan mendapatkan kain mori (cambrics) sebagai bahan baku pembuatan batik, hal ini terjadi karena para pedagang Cina tidak mau menjual kain mori secara tunai tetapi dengan cara kredit yang bunganya sangat tinggi. Oleh karena itu, para pengusaha batik yang memiliki modal kecil banyak yang gulung tikar.

Untuk mengatasi permasalahan tersebut dan menyelematkan industri batik Tasikmalaya, beberapa pengusaha berkumpul di rumah Raden Kartadibrata. Pertemuan para pengusaha batik itu berhasil membentuk sebuah koperasi yang kemudian diberi nama Pangroyong. Meskipun mendapat dukungan dari Bupati R.A.A. Wiratanuningrat, keberadaan Koperasi Pangroyong tidak dapat mengatasi kesulitan yang dihadapi oleh industri batik Tasikmalaya.

Di sisi lain, Pemerintah Hindia Belanda merasa terancam oleh ekspansi ekonomi Jepang yang produksi industrinya mulai dapat diterima oleh penduduk pribumi. Departement van Economische Zaken memandang bahwa ekspansi ekonomi Jepang itu dapat diatasi apabila pemerintah dapat bekerja sama dengan para Pengusaha. Tahun 1934, pengusaha batik Tasikmalaya menuntut kepada Pemerintah Hindia Belanda agar mereka dapat membeli kain mori langsung dari importir. Tetapi tuntutan tersebut ditolak oleh Departement van Economische Zaken.

Sejalan dengan itu, pada akhir tahun 1930-an, jenis usaha koperasi sedang gencar disosialisasikan oleh Pemerintah Hindia Belanda. Untuk keperluan itu, tahun 1938 Pemerintah Hindia Belanda menempatkan R.S.A. Kosasih di Tasikmalaya dengan tugas membina sektor koperasi di daerah tersebut. Kehadirannya dimanfaatkan oleh para pengusaha batik melalui Koperasi Mitra Batik untuk melobi para pejabat di Departement van Economische Zaken di Jakarta agar memberikan izin kepada mereka untuk dapat membeli kain mori dan bahan-bahan pembatikan lainnya langsung dari importir. Berkat upaya dari Koperasi Mitra Batik serta atas bantuan R.S.A. Kosasih, Pemerintah Hindia Belanda pada akhirnya mengeluarkan kebijakan yang mengizinkan pada Koperasi Mitra Batik membeli kain mori langsung dari importir. Keberhasilan ini membuat pedagang Cina di Kota Tasikmalaya mengalami kemunduran karena tidak mampu menghadapi konsolidasi para pengusaha batik yang semakin kuat pasca 
didirikannya Koperasi Mitra Batik. Para pedagang Cina tidak mampu mengonsolidasikan di antara mereka sehingga mereka berjalan sendiri-sendiri (Falah, 2010: 168-169).

Meski demikian, sejak pertengahan abad ke-19, barang kerajinan dari Kota Tasikmalaya sudah mendapatkan reputasi yang luas, terutama di kalangan orangorang Eropa, sehingga tidak heran sebagian dari barang tersebut diekspor ke Eropa. Di antara barang kerajinan yang paling diminati adalah anyaman pandan dan bambu. Berikut ini salah satu aktivitas penduduk Kabupaten Tasikmalaya yang memproduksi topi Panama. Penamaan atau brand Panama boleh jadi mengambil model topi tersebut dari topi-topi produksi Panama (Amerika Latin) yang sat itu sedang "trend". Karena itu, kemungkinan topi tersebut dibuat atas dasar pesanan orang-orang Belanda (Eropa) sehingga produksi kerajinan yang awalnya hanya sebagai barang seni menjadi memiliki fungsi, mengingat tradisi Eropa yang menjadikan topi sebagai barang fashion, sekaligus melindungi mereka dari cuaca panas.

$\begin{array}{ccr}\text { Untuk memperlancar } & \text { kehidupan } \\ \text { ekonomi } & \text { masyarakat, } & \text { Bupati }\end{array}$
Wiratanuningrat membangun jalan-jalan dan jembatan-jembatan sehingga memperlancar arus transportasi. Selain membangun fasilitas publik seperti jalan dan jembatan. Seperti yang diungkap Wirahadi Soeria bahwa untuk keperluan rakyat agar memudahkan dan melancarkan hubungan mata pencahariannya, Bupati R.A.A. Wiratanuningrat membangun beberapa jembatan, yaitu:

1. Jembatan Gantung Kawat jalan ke Ciwarak

2. Jembatan Gantung Kawat jalan ke Linggasari

3. Jembatan Gantung Kawat jalan ke Talegong

4. Jembatan Gantung Kawat jalan ke Leuwi Budah - Tanjung

5. Jembatan Gantung Kawat jalan ke Cigugur
6. Jembatan bambu beralas besi di Mangunjaya (sangat disayangkan jembatan ini tidak sampai selesai karena diterjang banjir kali Ciseel)

(Wirahadisoeria. tt. Sejarah Sukapura. Tidak diterbitkan dan (Hoofcomite Pangeling-ngeling 300 Taun Ngadegna Kabupaten Sukapura, 1932: 41).

Sampai dengan berakhirnya masa penjajahan Belanda, ulama di Indonesia terbagi atas dua kelompok yaitu ulama dependen dan ulama independen. Para ulama yang independen merupakan benteng rakyat yang menolak kolonialisme. Mereka terang-terangan menolak untuk kerja sama dengan pemerintah kolonial, bahkan secara terangterangan pula mengadakan gerakan perlawanan. Itulah sebabnya pemerintah kolonial mencap ulama sebagai "si pembuat rusuh" (trouble makers).

Sejak terjadinya peristiwa Cilegon pendidikan agama Islam dan gerak langkah para ulama diawasi oleh pemerintah kolonial, bahkan di Pulau Jawa terjadi "pemburuan terhadap guru agama". Gerak langkah guru dan pengajar agama Islam dibatasi oleh peraturan yang disebut Ordonansi Guru yang dikeluarkan pada tahun 1905. Dalam ordonansi itu antara lain disebutkan bahwa guru-guru agama Islam harus mendapat surat izin dari pemerintah (bupati) sebelum mereka melakukan tugasnya. Bila mereka melanggar ketentuan tersebut akan dikenakan hukuman kurungan maksimal delapan hari atau denda $f 25$. Pada waktu itu para bupati ditugaskan oleh pemerintah kolonial untuk mengawasi kegiatankegiatan terutama kegiatan para kiai. Agar para bupati dapat melaksanakan kewajiban tersebut dengan baik, pengaruh para bupati dalam bidang keagamaan tidak diganggu bahkan sebagian dari penghasilan mereka pun berasal dari bidang keagamaan, misalnya dari zakat fitrah (Alisyahbana, 1981: 8). Untuk mengadakan pendekatan dengan para alim ulama maka Bupati Wiratanuningrat mendirikan perkumpulan para alim ulama yang disebut "Idharu 
Baitil Mulukki Wal Umaro" yang artinya "Tuhu ka Ratu, tumut ka pamarentah nagara".

Mendirikan rumah fakir miskin Islam yang biayanya sebagian dari hasil zakat fitrah untuk fakir miskin. Biasanya hasil itu diberikan langsung setiap tahun kepada yang berhak menerima, tetapi karena kurang memberi manfaat untuk seterusnya, maka Bupati Wiratanuningrat berpendapat lebih baik mendirikan rumah penampungan bagi fakir miskin (Hoofcomite Pangeling-ngeling 300 Taun Ngadegna Kabupaten Sukapura, 1932: 44).

Pendidikan yang dijalankan oleh pemerintah kolonial pada dasarnya bertujuan untuk menjadikan warganegara yang mengabdi pada kepentingan penjajah. Dengan kata lain, pendidikan dimaksudkan untuk mencetak tenaga-tenaga yang dapat digunakan sebagai alat untuk memperkuat kedudukan penjajah, mengabdi kepada kepentingan pemerintah kolonial. Politik Etis telah mengubah pandangan dalam politik kolonial sehingga pemerintah Belanda beranggapan bahwa Indonesia tidak lagi sebagai "wingewest" (daerah yang menguntungkan) tetapi menjadi daerah yang perlu dikembangkan sehingga dapat memenuhi keperluannya, dan budaya rakyatnya ditingkatkan.

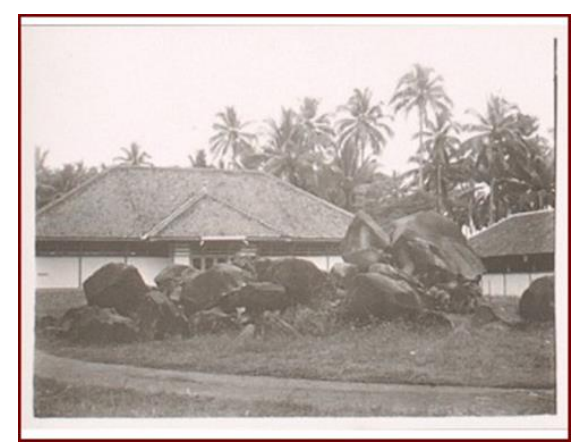

Gambar 3. Sekolah Teknik di Tasikmalaya (Ambachtsschool) Tahun 1933

Sumber: Koleksi Tropenmuseum.nl. Diakses dari

http://collectie.wereldculturen.nl/default.aspx?l ang=en, Tanggal 19 Juni 2017. Pukul 06.30 WIB.
Sekolah teknik atau vokasional sudah mulai muncul di kabupaten Tasikmalaya. Sekolah tersebut ditujukan untuk menghasilkan lulusan yang terampil dalam bidang skill tertentu. Salah satu contohnya adalah Sekolah Pertukangan. Berikut ini adalah Gedung Sekolah Teknik pada tahun 1930-an.

Paguyuban Pasundan mengadakan kongres pada tahun 1925 untuk mendirikan sekolah lanjutan yakni MULO (Meer Uitgebreid Lager Ounderwijs). Peserta kongres memberikan wewenang penuh kepada Bale Pawulangan Pasundan. Sebagai tindak lanjut setelah kongres, Bale Pawulangan Pasundan mengajukan izin operasional kepada pemerintah kolonial dan tiga tahun kemudian pemerintah kolonial mengabulkan permohonan tersebut. Sejak tahun 1928 di Tasikmalaya berdiri sekolah lanjutan yang bernama MULO Pasundan.

Jika saat ini Tasikmalaya dikenal sebagai Kota Santri, secara historis didukung oleh berdirinya pesantrenpesantren di kabupaten ini dari mulai tempat belajar yang paling sederhana (di Goa) sampai kepada pesantren yang sudah dalam bentuk pondok (kobong). Pesantren tua yang terdapat di Kabupaten Tasikmalaya adalah Pesantren Syekh Abdul Muhyi, melalui pesantrennya di Pamijahan yang berbasis di goa-goa. Kemudian Pesantren Suryalaya, Cintawana, Sukamanah, dan Cipasung. Pesantren Suryalaya didirikan pada 5 September 1905 oleh K.H. Abdullah Mubarak atau Abah Sepuh yang diawali dengan pendirian sebuah masjid yang dijadikan tempat mengaji dan mengajarkan Tarekat Qodiriyah wa Naqsabandiyah yang kemudian diberi nama Patapan Suryalaya Kajembaran Rahmaniyah sebagai cikal bakalnya (Lubis, dkk, 2011: 50). Pesantren ini pada perkembangan berikutnya menjadi pesantren yang mengatasi ketergantungan obat, hingga memiliki cabang sampai ke Brunei dan Malaysia.

Pesantren tua yang ada di Tasikmalaya adalah pesantren Condong 
(Riyadlul Ulum Wadda'wah) yang terletak di kampung Condong, Desa Condong, Kecamatan Cibeureum. Pesantren ini didirikan sekitar awal abad ke-19 oleh Kyai Nawawi yang berasal dari Rajapolah. Tanah yang dipergunakan untuk mendirikan pesantren itu, merupakan wakaf dari Pangeran Kornel, Bupati Sumedang. Dari pesantrennya itu, Kyai Nawawi menyebarkan ajaran Islam sehingga keberadaan pesantren di Kampung Condong menjadi dikenal oleh masyarakat Kota Tasikmalaya dan sekitarnya. Ketika didirikan, pesantren tersebut belum diberi nama Riyadlul Ulum Wadda'wah. Oleh masyarakat sekitarnya, pesantren ini dinamai Pesantren Condong, sesuai dengan nama kampung tempat pesantren itu berdiri (Falah, 2010: 195196).

Pada pertengahan tahun 1926, Bupati R.A.A. Wiratanuningrat mengumpulkan para ulama yang ada di Tasikmalaya. Dalam pertemuan tersebut Dalem Tasikmalaya itu mengutarakan niatnya membentuk sebuah perkumpulan yang akan menjadi wadah bagi para guru agama. Segala persiapan yang diperlukan untuk merealisasikan rencananya itu, diserahkan kepada ulama pakauman antara lain K.H. M. Soedja'i (Kudang, Bojong), K.H. M. Djakarsyi (Jajaway), K.H. M. Fahroerodji (Sukalaya), dan K.H. M. Fachroedin (Cikalang). Hasil kerja keempat ulama pakauman itu berupa rancangan pembentukan sebuah perkumpulan yang akan mempersatukan seluruh guru agama di Tasikmalaya. Rancangan itu diterima dan diresmikan oleh Bupati Wiratanuningrat tanggal 15 Juni 1926 dengan nama Perkumpulan Guru Ngaji (PGN). Peresmian perkumpulan itu dilaksanakan di Mesjid Agung Tasikmalaya yang dihadiri oleh seluruh wedana camat yang ada di Kabupaten Tasikmalaya (Falah, 2010: 229-230).

Dengan demikian, sebenarnya sebelum pendidikan model Barat diterapkan, masyarakat Kabupaten Sukapura-Tasikmalaya telah memiliki sistem pendidikan sendiri, yakni pesantren. Mencermati uraian di atas, diketahui bahwa perkembangan pesantren di Tasikmalaya ditentukan oleh beberapa faktor. Faktor pertama berkaitan dengan jumlah penduduk di Kabupaten Tasikmalaya sebagai pemeluk agama Islam. Bagi umat Islam, mencari ilmu merupakan sebuah kewajiban, dan di kota ini lahir banyak kiai yang dianggap mumpuni dalam menyebarkan agama Islam. Faktor kedua adanya anggapan bahwa sekolah formal yang dikenalkan oleh Pemerintah Hindia Belanda adalah 'haram' karena dikembangkan oleh orang 'kafir'. Hal ini menjadi semacam fatwa yang kemudian ditaati oleh masyarakat kabupaten ini. Sehingga, untuk mencari ilmu mereka lebih memilih pesantren dibanding sekolah formal. Faktor yang terakhir adalah adanya tuntutan dari para santri yang baru menyelesaikan pendidikannya di pesantren di luar kabupaten Tasikmalaya untuk mendirikan pesantren di daerahnya sendiri (Lubis, 2011: 194/195).

\section{PENUTUP}

Sebagai bupati yang bukan keturunan langsung dari "Dinasti Wiradadaha" yang memerintah di Kabupaten Sukapura dari abad ke-17 sampai dengan akhir abad ke-19, R.A.A. Wiratanuningrat, yang berasal 'trah' Dalem Bogor telah membangun Kabupaten Tasikmalaya dalam berbagai bidang, yang memperlihatkan kemajuan dalam aspek-aspek fisik dan nonfisik (1908-1937).

Melalui tangan 'dinginnya' tersebut Kabupaten Sukapura yang kemudian berganti nama menjadi Kabupaten Tasikmalaya (1913), maju pesat dalam berbagai bidang. Banyak hal yang luar biasa dilakukan bupati ini. Di antaranya mengubah lahan yang tidak potensial semacam Rawa Lakbok, menjadi wilayah yang produktif, memajukan perekonomian, yang ditandai dengan berdirinya perkebunan teh (Taraju), pada 1909 estafet 
pengelolaan kebun kopi, industri kerajinan, berdirinya lembaga keuangan semacam koperasi dan bank perkreditan, membangun lembaga pendidikan baik formal maupun yang berafiliasi keagamaan seperti masjid-masjid dan pesantren, di samping membangun berbagai infrastruktur. Dengan dibangunnya infrastruktur, maka aktivitas perekonomian masyarakat pun makin meningkat.

Untuk memperoleh historiografi yang bisa dipertanggungjawabkan secara akademis, tentang sejarah Kabupaten Sukapura/Tasikmalaya yang lengkap tampaknya memerlukan penelitian lebih lanjut, mengingat masih banyak periode yang belum bisa diungkapkan. Oleh karena itu disarankan melakukan penelitian terhadap periode-periode kepemimpinan para bupati keturunan Wiriadadaha dari IXII. Pencarian sumber yang lebih meluas dan mendalam dalam meneliti Sejarah Kabupaten Sukapura/Tasikmalaya diperlukan lebih serius lagi agar hasil yang diperoleh akan menghasilkan general history.

\section{UCAPAN TERIMA KASIH}

Penulis mengucapkan terima kasih kepada Prof. Dr. Nina Herlina Lubis, MS dan Dr. Widyo Nugrahanto, M.Si. yang telah memberikan arahan dan bimbingan dalam penelitian ini. Terima kasih juga penulis ucapkan kepada staf Perpustakaan Nasional Republik Indonesia (PNRI), Arsip Nasional Republik Indonesia (ANRI), Perpustakaan FIB UNPAD, dan semua pihak yang telah membantu dalam pengumpulan sumber.

\section{DAFTAR SUMBER}

\section{Arsip dan Dokumen Tercetak}

Conduite Staat van de Inlandsche Ambtenaren over het jaar en 1913, 1925. No. Jakarta: Arsip Nasional RI.

Rengeerings-Almanak voor Nederlansch-Indie. 1908, 1909 \& 1919. Tweede Gedeelte. Batavia: Landsdrukkerij.

\section{Buku}

Falah, Miftahul. 2010.

Sejarah Kota Tasikmalaya. Bandung: Uga Tatar Sunda; Yayasan Masyarakat Sejarawan Indonesia Cabang Jawa Barat.

Hardjasaputra, A. Sobana. 1985.

Bupati-Bupati Priangan; Kedudukan dan Peranannya Pada Abad ke-19. Yogyakarta: Universitas Gadjah Mada.

Hoofcomite Pangeling-ngeling 300 Tahun Ngadegna Kabupaten Sukapura. 1932. Pangeling-ngeling $300 \quad$ Tahun Ngadegna Kabupaten Sukapura. Tasikmalaya.

Kartodirdjo, Sartono., dkk. 1987.

Perkembangan Peradaban Priyayi. Yogyakarta: UGM.

Lubis, Nina H. 1998.

Kehidupan Kaum Menak Priangan 1800-1942. Bandung: Pusat Informasi Kebudayaan Sunda. Yayasan Obor Indonesia. 2014.

Metode Sejarah (edisi revisi). Bandung: YMSI.

Marlina, Itje., dalam Lubis,dkk. 2000. Sejarah Kota-Kota Lama di Jawa Barat. Bandung: Alqaprint.

Sutherland, Heather. 1983. Terbentuknya Sebuah Elite Birokrasi. Terj. Jakarta: Sinar Harapan.

Wirahadisoeria. tt. Sejarah Sukapura. Tidak diterbitkan.

\section{Tesis dan Disertasi}

Alisjahbana, Samiati. 1954.

A Preliminary Study of Class Structure among the Sundanese in the Priangan. Tesis unpublished. New York: Cornell University.

Hardjasaputra, A.Sobana. 2002. Perubahan Sosial di Bandung 18101906. Disertasi. Depok: Universitas Indonesia.

Yulifar, Leli. 2014. Kabupaten Galuh-Ciamis 1809-1942 (Pemerintahan, Sosial Ekonomi dan Politik). Disertasi. Bandung: Pascasarjana Universitas Padjadjaran. 


\section{Majalah dan Surat Kabar}

Pandji Poestaka No. 69, Agustus 1933 Tahoen XI

\section{Internet}

www.tropenmuseum.nl, Diakses 16-20 Juni

2017 